\title{
Economic justification of the use of bicomponent beverages based on pectin substances on the example of vegetable juices
}

\author{
Lyudmila V. Donchenko and Anna I. Belousova* \\ Kuban State Agrarian University named after I.T. Trubilin, Krasnodar, Russia
}

\begin{abstract}
Modern food technologies are not able to preserve the healthy components of original natural raw materials in finished products. The example is the production of industrial juices. It is known that freshly squeezed juices quickly deteriorate. In order to preserve their vitamins, useful components and increase the shelf life, water is immediately removed from freshly squeezed juices in a vacuum at a temperature of 30 ${ }^{\circ} \mathrm{C}$. It is known that water is not only an environment favorable for the bacteria reproduction, but also a strong chemical reagent that easily decomposes all the useful components contained in food. In addition, chemical interactions occur in the water, that is, decomposition reactions, and they can only be stopped by removing water from the food system. When sterilized by heating, the chemical processes of decomposition of healthy aromatic components are accelerated. As a result, the nutritional value of such drinks is reduced. The main trend in food market is the expansion of range and volume of production of functional beverages containing the necessary nutrients.
\end{abstract}

The research is carried out in the continuation of the problem of the completed Master's thesis: "Development of technology for bicomponent functional drinks" [1].

Bicomponent drinks are drinks consisting of two components - water and concentrated juice. It is almost impossible to find them in the food market. Unusual consumption of such products makes them more interesting and attractive, and therefore cost-effective for the manufacturer at the first stages of production. To maintain demand over time, it will be necessary to expand the range of products.

In modern conditions, one of the most characteristic features of the development of Russian economy is the tightening of competition, the availability of which contributes to improving the quality of goods and services produced, allows the most effective use of existing knowledge and experience, and provides the most complete satisfaction of human needs through the rational behavior of enterprises in the market. The development of practical recommendations for improving the competitiveness of the enterprise and increasing its competitive advantages based on the justification of the enterprise competitiveness model will allow us to formulate recommendations for improving the competitiveness of positions. The efficiency of production expresses the degree of

*Corresponding author: sergey_belousov_87@mail.ru 
achievement of main goals characteristic for extended reproduction. Economic efficiency is determined by comparing the resulting effect (result) with resources or costs used to obtain it [2]

Manufacturers of such analogues in the market of this product are the following:

- The LLC “Zelena Sova”, production of drinks on apple juice without added sugar, citric acid, preservatives, E-additives, without pasteurization and sterilization, special drinks for athletes.

- The LLC “Amway”, therapeutic drinks.

- The LLC “Triel”, dehydrated compositions of concentrated juices, plant extracts.

The formula of competitiveness of food products is as follows

$$
\mathrm{K}_{\mathrm{pr}}=\mathrm{B} \sum \mathrm{m}_{\mathrm{i}} \mathrm{g}_{\mathrm{i}} / \mathrm{C}
$$

where $\sum \mathrm{m}_{\mathrm{i}} \mathrm{g}_{\mathrm{i}}$ - the total complex indicator of quality level, expressed in points $\left(\mathrm{m}_{\mathrm{i}}-\right.$ weighting coefficient and $\mathrm{g}_{\mathrm{i}}$ - the quality indicator of the i-th property);

$\mathrm{C}$ - price per unit of a product;

$\mathrm{B}$ - product safety.

Product safety when calculating competitiveness takes into account the absence or presence of clinical trials. As a result, the fraction is multiplied by 0 (the product is not competitive), or by 1 (the product is competitive), or by 2 (the product has functional properties and is highly competitive).

The quality rating scale includes three levels:

- good products (4 points) - competitive products;

- satisfactory (3 points) - products that can compete with best samples for a while;

- bad products ( 2 points) - products that can compete with the best analogues only in the near future, but not in the future.

It should be noted that some indicators are fundamental, while others can be classified as secondary. In this regard, the weighting coefficient is introduced for an objective assessment. As a result of summation, it should be a multiple of 10 for convenience when calculating [3, 4].

When evaluating the competitiveness of beverages developed by us, the sum of points was made up of values of standard indicators: appearance, color, taste, aroma, mass fraction of dry substances, nutritional value, warranty period of storage. Thus, when constructing the rating scale, first of all, we took into account standard indicators that characterize harmlessness, as well as new indicators with advanced characteristics, with stricter requirements for the quality of the product, packaging, design and storage, as well as such novelty in the market of juice products as bicomponent drinks. As the objects of evaluation, we selected the drinks "Light vegetable" and "Spicy vegetable"

Table 1 shows the scale of assessing the competitiveness of studied vegetable drinks.

Taking into account the developed scale of competitiveness of the developed beverages, we have evaluated it. The results of the study are presented in Table 2.

Thus, competitiveness implies the need to expand production to enter the Russian market, as well as abroad. Expanding the product range will attract potential buyers of any age. 
Table 1. Competitiveness assessment scale

\begin{tabular}{|c|c|c|c|c|c|c|c|}
\hline \multirow[t]{2}{*}{ Rate } & \multirow{2}{*}{$\begin{array}{l}\text { Weig } \\
\text { ht } \\
\text { ratio }\end{array}$} & \multicolumn{3}{|c|}{ Quality level } & \multicolumn{3}{|c|}{ Characteristics of the quality level } \\
\hline & & $\begin{array}{l}4 \\
\text { point } \\
\text { s } \\
\end{array}$ & $\begin{array}{l}3 \\
\text { point } \\
\text { S }\end{array}$ & $\begin{array}{l}2 \\
\text { point } \\
\mathrm{s} \\
\end{array}$ & Good (4) & Satisfactory (3) & Unsatisfactory (2) \\
\hline \multicolumn{8}{|c|}{ Standard indicators } \\
\hline Taste & 3 & 12 & 9 & 6 & harmonious & Ordinary & $\begin{array}{l}\begin{array}{l}\text { Extraneous tones } \\
\text { (colors) }\end{array} \\
\end{array}$ \\
\hline Color & 2 & 8 & 6 & 4 & $\begin{array}{l}\text { Bright, } \\
\text { characteristic of } \\
\text { raw materials }\end{array}$ & Not bright & $\begin{array}{l}\text { Dirty tones in } \\
\text { coloring }\end{array}$ \\
\hline Smell & 10 & 40 & 30 & 20 & $\begin{array}{l}\text { Well-developed, } \\
\text { characteristic of } \\
\text { raw materials }\end{array}$ & Underdeveloped & $\begin{array}{l}\text { With extraneous } \\
\text { tones (colors) }\end{array}$ \\
\hline Consistency & 5 & 20 & 15 & 10 & $\begin{array}{l}\text { Homogeneous, } \\
\text { semi-liquid }\end{array}$ & $\begin{array}{l}\text { Inhomogeneous, semi- } \\
\text { liquid }\end{array}$ & $\begin{array}{l}\text { Too thick or too } \\
\text { liquid }\end{array}$ \\
\hline Appearance & 5 & 20 & 15 & 10 & $\begin{array}{l}\text { Clear or / and } \\
\text { cloudy liquid }\end{array}$ & With sediments & $\begin{array}{l}\text { With the formation } \\
\text { of sediments }\end{array}$ \\
\hline $\begin{array}{l}\text { Mass fraction } \\
\text { of soluble } \\
\text { solids, \% }\end{array}$ & 3 & 12 & 9 & 6 & $\begin{array}{l}\text { Complies with } \\
\text { GOST (from } 5 \\
\text { to 18) }\end{array}$ & $3-5$ & Less 3 \\
\hline $\begin{array}{lr}\text { Mass } & \text { fraction } \\
\text { of } & \text { titrated } \\
\text { acids } & \text { per } \\
\text { citric acid,\% }\end{array}$ & 3 & 12 & 9 & 6 & More 0,2 & 0,2 & Less 0,2 \\
\hline $\begin{array}{l}\text { Mass } \\
\text { of fraction } \\
\text { substances, } \%\end{array}$ & 10 & 40 & 30 & 20 & $0,9-1,5$ & $0,5-0,9$ & $0,2-0,5$ \\
\hline \multicolumn{8}{|c|}{ Market research indicators } \\
\hline $\begin{array}{l}\text { New } \\
\text { packaging for } \\
\text { drinks }\end{array}$ & 10 & 40 & 30 & 20 & $\begin{array}{c}\text { Protected by } \\
\text { patent }\end{array}$ & Not protected by patent & Absent \\
\hline $\begin{array}{l}\text { Novelty in the } \\
\text { market of } \\
\text { juice products }\end{array}$ & 10 & 40 & 30 & 20 & $\begin{array}{l}\text { Rarely found on } \\
\text { sale }\end{array}$ & $\begin{array}{l}\text { Available only in } \\
\text { specialty stores }\end{array}$ & In free sale \\
\hline Shelf life & 10 & 40 & 30 & 20 & more a year & Year & Less a year \\
\hline Trademark & 5 & 20 & 15 & 10 & Protected & Not proptected & Absent \\
\hline $\begin{array}{l}\text { Information } \\
\text { content of the } \\
\text { label }\end{array}$ & 5 & 20 & 15 & 10 & Full information & $\begin{array}{l}\text { The information is } \\
\text { shown in small print }\end{array}$ & $\begin{array}{l}\text { There is no turnover } \\
\text { sign on the market }\end{array}$ \\
\hline $\begin{array}{l}\text { Market } \\
\text { analysis, } \\
\text { demand } \\
\end{array}$ & 10 & 40 & 30 & 20 & $\begin{array}{l}\text { No competitors, } \\
\text { high demand }\end{array}$ & $\begin{array}{l}\text { Weak competition and } \\
\text { demand }\end{array}$ & $\begin{array}{l}\text { Strong competition } \\
\text { demand is not set }\end{array}$ \\
\hline $\begin{array}{l}\text { Comprehensi } \\
\text { ve indicator }\end{array}$ & 100 & 400 & 300 & 200 & & & \\
\hline Harmlessness & 10 & 40 & 30 & 20 & $\begin{array}{l}\text { There are } \\
\text { hygienic } \\
\text { conclusions and } \\
\text { the conclusion } \\
\text { of the health } \\
\text { authorities }\end{array}$ & $\begin{array}{l}\text { There are hygienic } \\
\text { conclusions of the } \\
\text { developed drink }\end{array}$ & $\begin{array}{l}\text { There are no } \\
\text { hygienic } \\
\text { conclusions }\end{array}$ \\
\hline
\end{tabular}


Table 2. Competitiveness of developed vegetable drinks

\begin{tabular}{|c|c|c|c|c|c|c|}
\hline \multirow[t]{2}{*}{ Rate } & \multirow{2}{*}{$\begin{array}{l}\text { Weight } \\
\text { ratio }\end{array}$} & \multicolumn{3}{|c|}{ Quality level } & \multicolumn{2}{|c|}{ Evaluation of beverage samples } \\
\hline & & $\begin{array}{c}4 \\
\text { point } \\
\text { s }\end{array}$ & $\begin{array}{c}3 \\
\text { points }\end{array}$ & $\begin{array}{c}2 \\
\text { points }\end{array}$ & $\begin{array}{c}\text { "Light } \\
\text { vegetable" }\end{array}$ & "Spicy vegetable" \\
\hline Taste & 3 & 12 & 9 & 6 & 12 & 12 \\
\hline Color & 2 & 8 & 6 & 4 & 8 & 8 \\
\hline Smell & 10 & 40 & 30 & 20 & 30 & 40 \\
\hline Constency & 5 & 20 & 15 & 10 & 20 & 20 \\
\hline Appearance & 5 & 20 & 15 & 10 & 15 & 15 \\
\hline Mass fraction of SV & 3 & 12 & 9 & 6 & 12 & 12 \\
\hline $\begin{array}{l}\text { Mass fraction of titrated } \\
\text { acids }\end{array}$ & 3 & 12 & 9 & 6 & 12 & 12 \\
\hline $\begin{array}{l}\text { Mass fraction of pectin } \\
\text { substances, \% }\end{array}$ & 10 & 40 & 30 & 20 & 40 & 40 \\
\hline New packaging for drinks & 10 & 40 & 30 & 20 & 40 & 40 \\
\hline $\begin{array}{l}\text { Novelty in the market of } \\
\text { juice products }\end{array}$ & 10 & 40 & 30 & 20 & 40 & 40 \\
\hline Shelf life & 10 & 40 & 30 & 20 & 40 & 40 \\
\hline Trademark & 5 & 20 & 15 & 10 & 20 & 20 \\
\hline $\begin{array}{l}\text { Informative content of the } \\
\text { label }\end{array}$ & 5 & 20 & 15 & 10 & 15 & 15 \\
\hline Market analysis, demand & 10 & 40 & 30 & 20 & 30 & 30 \\
\hline Comprehensive indicator & 100 & 400 & 300 & 200 & 334 & 344 \\
\hline Harmlessness & & & & & 2 & 2 \\
\hline Price for 1 piece, rub & & & & & 40 & 40 \\
\hline Competitiveness, \% & & & & & 16,7 & 17,2 \\
\hline
\end{tabular}

\section{References}

1. Belousova A. I. Development of agricultural processes in modern economic conditions Belousova A. I., Belousov S. V. In the proceedings: Scientific support of the agro-industrial complex. Collection of articles based on the materials of the $73^{\text {rd }}$ scientific and practical conference of students on the results of researches in 2017. Chief editor A.G.Koshchaev. 2018. pp. 344-346.

2. Poznyakovsky V. M., Kiselev V. M., Schmidt V. V. Assortment of functional drinks on the regional market / / Beer and beverages, 2009. - No.5.

3. Technical regulations of the Customs Union TP CU 021/2011 "On food safety", approved by the Decision of the Customs Union Commission dated 09.12.2011. No. 880. - 242 p.

4. Technical regulations of the Customs Union TP CU 023/2011 "Technical regulations for fruit and vegetable juice products", approved by the Decision of the Customs Union Commission dated 09.12.2011. No. 882. - 242 s 